\title{
KEPEMIMPINAN KIAI DALAM IDEOLOGISASI PEMIKIRAN SANTRI DI PESANTREN-PESANTREN SALAFIYAH MLANGI YOGYAKARTA
}

\author{
Zainal Arifin \\ UIN Sunan Kalijaga Yogyakarta \\ derizzain@yahoo.co.id
}

\begin{abstract}
This research discusses about kyai's leadership within santri's ideological thought in Pesantren Salafiyah, Mlangi, Yogyakarta. There are more than 16 Pesantren Salafiyah in Mlangi, However, this qualitative research covers only five of them taken as purposive sampling. Data collection was conducted through in depth interview, observation, and documentation. The result shows that (1) The Kyai's leadership is categorized under Weber's theory of domination namely traditional, charismatic and rational, (2) Ablussunah Waljamaah (Aswaja) an-Nabdliyah was held as the community's ideology which is taught to santri by means of teaching Aswaja an-Nahdliyah classical books, strengthening alumnae allegiance, fostering Pesantren Salafiyah traditions, conducting Babtsul Masa'il and Tafaqqub fiddin, regenerating young constituent by joining Nahdhatul Ulama membership, as well as by studying cross-Islamic school of thought (ideology), and (3) the implications of this type of leadership on santri's thought are fanatical attitude in following kyai's religious thought (affected by traditional and charismatic leadership), non-dichotomical viewpoint on science and religion, and broader borizon on Islamic knowledge by studying contemporary Islamic books (affected by rational leadership).
\end{abstract}

Keywords: Leadership, Kiai-Santri, Salafiyyah, Aswaja an-Nahdliyah.

\begin{abstract}
Abstrak
Penelitian ini membahas kepemimpinan kiai dalam ideologisasi pemikiran santri di Pesantren-pesantren Salafiyah Mlangi Yogyakarta. Di Mlangi terdapat lebih dari 16 pondok pesantren Salafiyah. Jenis penelitian ini adalah kualitatif dengan mengambil lima pesantren. Pengumpulan data dilakukan dengan wawancara mendalam, observasi, dan dokumentasi. Hasil penelitian menunjukkan babwa tipologi kepemimpinan kiai di Pesantren-pesantren Salafiyah Mlangi berdasarkan teori dominasi Weber, yaitu tradisional, kharismatik, dan rasional, ideologi yang dianut adalah Ablussunah Waljamaah (Aswaja) an-Nahdliyah dan strategi ideologisasi santri melalui kajian kitab-kitab klasik bermadzab Aswaja anNahdliyah, penguatan alumni, melestarikan tradisi pesantren Salafiyah, Babtsul Masa'il dan Tafaqquh fiddin, kaderisasi dengan keikutsertaan pada organisasi NU, kajian lintas madzhab (ideologi), dan implikasi tipe kepemimpinan kiai terhadap pemikiran santri adalah bersikap fanatik dalam mengikuti pemikiran keagamaan santri (dipengarubi kepemimpinan tradisional dan karismatik) dan santri tidak memiliki pandangan dikotomik antara ilmu agama dan sains dan memiliki wawasan pengetahuan Islam yang lebih luas dengan kajian kitab-kitab Islam kontemporer (dipengarubi kepemimpinan rasional).
\end{abstract}

Kata Kunci: Kepemimpinan, Kiai-Santri, Salafiyyah, Aswaja an-Nahdliyah.

Permalink/DOI: http://dx.doi.org/10.18326/infsl3.v9i2.351-372 


\section{Pendahuluan}

Kiai dalam bahasa Jawa dipakai untuk tiga jenis gelar yang saling berbeda. Pertama, sebagai gelar kehormatan bagi barang-barang yang dianggap kramat, misalnya "Kiai Garuda Kencana" sebutan Kereta Emas di Kraton Yogyakarta. Kedua, gelar kehormatan untuk orang tua, dan ketiga, gelar yang diberikan oleh masyarakat kepada seseorang ahli agama Islam yang memiliki atau menjadi pemimpin pesantren. (Zamakhsari Dhofier, 2011: 55).

Menurut Karel A. Steenbrink (1986:109-110), dalam masyarakat tradisional, seorang dapat menjadi kiai karena diterima masyarakat sebagai kiai dan orang datang minta nasehat kepadanya, atau mengirimkan anaknya supaya belajar kepada kiai. Untuk menjadi Kiai, tidak ada kriteria formal. Namun, menurut H. Aboebakar Atjeh yang dikutip Steenbrink, menyebutkan beberapa faktor yang menyebabkan seseorang menjadi kiai besar, yaitu: pengetahuan, kesalehan, keturunan, dan jumlah muridnya.

Zamakhsari Dhofier berpendapat bahwa kiai merupakan sumber mutlak dari kekuasaan dan kewenangan dalam kehidupan dan lingkungan pesantren (Z. Dhofier, 2011: 93-94). Abdurrahman Wahid menjelaskan bahwa seorang kiai memiliki hierarki kekuasaan satu-satunya yang secara eksplisit diakui dalam lingkungan pesantren. Kekuasaan kiai absolut, sehingga santri seumur hidupnya akan senantiasa merasa terikat dengan kiainya. (Abdurrahman Wahid, dalam M. Dawam Rahardjo (ed.), 1995: 42-43).

Kepemimpinan kiai di pesantren bersumber pada kombinasi antara (tradisi) pendidikan Islam dan karisma yang diperoleh atau diwarisi (secara geneologis) (Inayah Rohmaniyah dan Mark Woodward, 2012: 123) atau sifat kepemimpinan kharismatik kiai (Sukamto, 1999: 23). Kepemimpinan kharismatik memiliki persuasi kuat dalam menanamkan ideologi (Chumaidi Syarif Romas, 2003: 205). Pemimpin karismatik dapat diperoleh secara given, seperti tubuh yang besar, suara yang keras, dan mata yang tajam serta adanya ikatan geneologis dengan kiai karismatik sebelumnya dan proses perekayasaan (Abdur Rozaki, 2004: 87-88). 
Dalam pesantren, khususnya pesantren tradisional, proses ideologisasi pemikiran Islam dari kiai kepada santri sangat penting untuk mempertahankan tipologi ideologi yang diyakininya. Dapat kita lihat bagaimana para santri dan lulusan sebuah pesantren tradisional menyakini sepenuhnya kebenaran ideologi/pemikiran keagamaan kiai. Hal ini sedikit berbeda dengan pesantren modern, misalnya Gontor. Proses ideologisasi pemikiran Islam lebih inklusif tidak seekslusif di pesantren tradisional (salafiyah). Hal ini dapat dibuktikan, alumni Gontor bisa menjadi pemimpin organisasi Islam yang berbeda-beda, misalnya Din Syamsudin (mantan ketua umum Muhammadiyah), Hasyim Muzadi (mantan ketua PBNU), Abdullah Said (mantan ketua umum Hidayatullah), Hidayat Nur Wahid (mantan ketua umum PKS), dan lain sebagainya.

Mengapa penelitian ini penting dilakukan di Mlangi dengan subyek para kiai dan santri pesantren di wilayah kampung tersebut? Karena, di dalam kampung Mlangi ini terdapat lebih dari 16 pondok pesantren Salafiyah dan 3 masjid, yaitu Masjid Jami' (Pathok Negoro Kraton Ngayogyakarta), Masjid Ledok (di pinggir sungai), dan Masjid Al-Awwab di Mlangi Kidul. Selain itu, ada banyak mushola yang jadi satu dengan pesantren. Sehingga, dusun Mlangi sering disebut sebagai dusun santri, bahkan pemerintah Kabupaten Sleman dan Provinsi D.I. Yogyakarta menjadikan kampung tersebut sebagai kampung wisata religi dengan sebutan Desa Wisata Religius Islami (Zainal Arifin (a), 2012: 93).

Penelitian ini bertujuan untuk menemukan dan mengkaji pola kepemimpinan kiai, strategi kepemimpinan kiai dalam proses ideologisasi pemikiran santri di Pesantren-pesantren salafiyah Mlangi, dan bagaimana implikasi kepemimpinan kiai terhadap pemikiran santri dalam memahami ajaran agama Islam.

\section{Landasan Teori}

\section{Teori Kepemimpinan}

Pisau analisis dalam penelitian ini adalah teori kepemimpinan Max Weber dan model kepemimpinan dalam suatu organisasi pendidikan. Weber yang membagi pola kepemimpinan berdasarkan 
dengan teori dominasinya menjadi tiga, yaitu kepemimpinan tradisional, karismatik, dan rasional. Bryan S. Turner (1974:23) menjelaskan teori Weber ini, bahwa kepemimpinan legal (rasional) bersumberkan pada keyakinan legalitas atas dasar aturan dan prosedur yang berlaku, kepemimpinan tradisional bersumberkan pada otoritas tradisi masyarakat tertentu, sedangkan kepemimpinan karismatik bersumberkan pada kesucian, kepahlawanan, dan kualitas (karakter) luar biasa dari pemimpinnya atau menurut Abdul Gaffar Karim (2009: 103), karisma muncul berdasarkan pada kualitas spiritual seorang pemimpin.

Horikoshi (1987: 226-227) menjelaskan dua prasyarat sosok karismatik, yaitu memiliki sifat ideal yang dijunjung tinggi dan kemampuan yang sulit dicapai atau dipertahankan oleh sekelompok masyarakat (sekultur). Dalam tradisi pesantren, pengaruh karisma kiai terletak pada keyakinan pengikutnya bahwa kiai mempunyai sifat-sifat transendental, menjadi teladan sempurna bagi semesta dan merupakan contoh hidup tentang ma'rifat.

\section{Pesantren Salafiyah}

Pesantren Salafiyah secara umumnya diartikan sebagai pesantren tradisional yang masih memegang kuat tradisi dalam pembelajaran kitab-kitab klasik (kitab kuning). Istilah salafi atau salafiyah dalam KBBI berarti sesuatu atau orang yang terdahulu, ulama-ulama terdahulu yang saleh (Tim Penyusun Kamus Pusat Bahasa, 2002: 982). Di dalam masyarakat Islam, istilah pesantren salafi dan salafiyah seringkali mengandung tradisi keagamaan yang berbeda. Pertama, pesantren salafiyah merupakan pesantren tradisional yang mengkaji kitab-kitab Syafi'iyah dalam bidang usul fikih dan fikih, kitab-kitab Asy'ariyah dan Maturidiyah dalam bidang tauhid, dan kitab-kitab Al-Gazali dalam bidan filsafat dan tasawuf. Mayoritas pesantren ini didirikan oleh organisasi Islam, seperti Nahdlatul Ulama (NU) (Zainal Arifin (b) 2012): 47).

Kedua, pesantren salafi dimaknai sebagai pesantren yang secara konsisten mengikuti ajaran ulama generasi sahabat, tabi'in, tabi'at tabi'in yang memiliki kecenderungan pada penafsiran teks secara normatif (literal) dan kurang mengapresiasi budaya setempat. 
Model penafsiran terhadap teks agama bersifat literalistik. Menurut Subhan (2012: 281), model penafsiran normatif (literal) inilah yang kadang menjadikan gerakan salafi menjadi gerakan radikal dalam Islam. Misalnya, dalam berpakaian bagi laki-laki memakai jubah, kewajiban memelihara jenggot, sedangkan bagi perempuan memakai jubah dan cadar.

Adapun yang dimaksud dengan pesantren salafiyah dalam penelitian ini adalah pesantren tradisional yang masih melestarikan tradisi kajian kitab-kitab klasik serta memiliki pemikiran keagamaan yang moderat dan menghargai tradisi masyarakat sekitarnya. Pesantren yang dijadikan obyek penelitian ini adalah pesantren tradisional yang berafiliasi kepada organisasi Islam Nahdlatul Ulama (NU) di kampung Mlangi Sleman Yogyakarta.

\section{Metode Penelitian}

Penelitian ini adalah penelitian lapangan (field research) dengan pendekatan kualitatif deskriptif. Fokus penelitian untuk mengungkap pola kepemimpinan kiai, strategi kepemimpinan kiai dalam proses ideologisasi pemikiran santri di Pesantren-pesantren salafiyah Mlangi Yogyakarta, dan implikasi kepemimpinan kiai terhadap pemikiran santri dalam memahami ajaran agama Islam.

Teknik pengumpulan data menggunakan, wawancara mendalam (in-depth interviews), observasi, dan an dokumentasi (Sugiyono, 2010: 305). Teknik penentuan sumber data dalam penelitian ini menggunakan purposive sampling, yaitu mengambil lima pesantren yang dianggap sudah mewakilinya, yaitu Pondok Pesantren as-Salafiyah, Aswaja Nusantara, Al-Miftah, al-Falahiyah, dan an-Nasyath. Analisis data menggunakan model interaktif Miles dan Huberman (1984: 21-23), yaitu reduksi data (data reduction), penyajian data (data display), dan penarikan kesimpulan/verifikasi (conclusion drawing/verification). 


\section{Analisis Hasil Penelitian}

Pola Kepemimpinan Kiai di Pesantren-Pesantren Salafiyah di Mlangi

Dunia pesantren sarat dengan aneka pesona, keunikan, kekhasan dan karakteristik tersendiri yang tidak dimiliki oleh institusi lainnya. Kepemimpinan kiai di sebuah pondok pesantren memegang teguh nilai-nilai luhur yang menjadi acuannya dalam bersikap, bertindak, dan mengembangkan pesantren. Pola kepemimpinan kiai dalam pendidikan pesantren sangat esensial. Hidup atau matinya sebuah pesantren tergantung pada pola kepemimpinan kiai yang dijalankan di pesantren itu. Kepemimpinan kiai dalam mengelola pesantren tidak hanya dilandasi kemampuan mengatur pesantren, akan tetapi juga dilandasi kekuatan spiritual dan nilai-nilai ketaatan kepada Allah Swt. Atas dasar inilah, kiai mampu menjadi aktor perubahan sosial.

Suatu pesantren dapat diibaratkan sebagai suatu kerajaan kecil di mana kiai memiliki kekuasaan dan kewenangan mutlak dalam kehidupan dan lingkungan pesantren (Z. Dhofier, 2011: 94). Tidak seorang pun santri atau masyarakat yang dapat melawan kekuasaan kiai di lingkungan pesantren kecuali kiai lain yang lebih besar karismanya. Para santri selalu berpikir bahwa kiai yang dianutnya merupakan orang yang percaya penuh kepada dirinya sendiri (self confident), baik dalam soal-soal pengetahuan Islam, maupun dalam bidang kekuasaan dan manajemen pesantren.

Dalam hal kepemimpinan, para kiai memiliki pola kepemimpinan yang berbeda antar satu kiai dengan kia lainnya. Hal ini dapat dilihat pada pesantren-pesantren salaf di Mlangi. Misalnya, Pondok Pesantren al-Falahiyah yang didirikan pada tahun 1963 oleh KH. Zamruddin dan Nyai Hajjah Rubai'ah adalah pondok pesantren putri pertama yang fokus pada bidang tahfidz al-Qur'an. Al-Falahiyah merupakan pondok pesantren ketiga yang di bangun di Mlangi setelah Pondok Pesantren Salafiyah dan Al-Miftah. Saat ini, pesantren tersebut diasuh oleh Muhammad Rifqi Aziz putra $\mathrm{KH}$ Zamruddin atau yang dikenal dengan sebutan Gus Rifqi. 
Pondok Pesantren al-Falahiyah memiliki sekolah formal pada jenjang pendidikan dasar, yaitu Madrasah Ibtidayah (MI) al-Falahiyah. Jumlah santri yang tinggal di Pondok Pesantren sekitar 180 anak. Selain itu, ada sekitar 10 santri merupakan santri kalong yang berasal dari daerah sekitar pondok pesantren. Mayoritas ideologi para santri berasal dari kalangan keluarga Nahdlatul Ulama (NU), meskipun ada juga salah satu wali santri yang berasal dari Muhammadiyah yang kemudian mengikuti amaliyah pesantren. Menurut Gus Rifqi, tujuan pendidikan di Pesantren al-Falahiyah untuk pembentukan akhlak dan tahfiz al-Qur'an dengan memberikan teladan, praktek ibadah sunah dan ritual mujahadah. Selain itu, pesantren ini mengkaji kitab-kitab fikih Syafi'iyah dan tauhid Asy'ariyah (Wawancara, 3 Oktober 2015). Kitab-kitab ini sebagai ciri khas pendidikan Islam di pesantren tradisional yang dikelola oleh kiai NU.

Keputusan-keputusan strategis dalam manajemen pesantren ditentukan oleh kiai dan hal-hal yang terkait aturan pesantren alFalahiyah ini menerapkan sikap demokratis kepada para pengurus dan pengajarnya. Segala sesuatunya yang terkait aturan dan manajemen pondok dimusyawarahkan dengan pengurus pondok dan juga pengurus madrasah. Menurut Gus Rifqi, walaupun keputusan-keputusan itu merupakan hasil musyawarah, kiai sebagai pengasuh pondok pesantren tetap memiliki kewenangan kuat dalam hal keputusan dan pelaksanaan (Wawancara, 3 Oktober 2015). Kewenangan kiai dalam memutuskan sangat dihormati oleh para pengurus pesantren karena kiai memiliki karisma, selain itu dalam tradisi pesantren, kiai sangat dihormati dalam pengambilan keputusan apa pun.

Model kepemimpinan kiai di Pondok Pesantren al-Falahiyah sedikit berbeda dengan kepemimpinan Pondok Pesantren asSalafiyah yang didirikan oleh Kiai Masduki pada tahun 1932 dan saat ini dipimpin oleh KH. Syuja'i Masduki. Menurut Gus Irwan Masduqi, al-Salafiyah merupakan pondok tertua di Mlangi dan memiliki santri sekitar 610 anak (307 santri putri dan 360 santri putra). Di pondok ini, dikaji berbagai kitab-kitab klasik dan juga kitab kontemporer seperti karya Rusyd, Sayyid Quthb, Wahbah Zuhaili, dan lain-lain. Selain itu, al-Salafiyah juga menjadi pusat thoriqah Naqsyabandiyah (pimpinan Salafiyah menjadi Mursyid Naqsyabandiyah). Pada tahun 2013 
telah mendirikan pendidikan formal seperti Madrasah Tsanawiyah (MTs) dan tahun 2015 mulai membangun Madrasah Aliyah (MA). (Wawancara, 11 Oktober 2015).

Pendirian sekolah formal di Pondok Pesantren al-Salafiyah mengindikasikan adanya perubahan orientasi pendidikan Islam dari sistem pesantren tradisional yang fokus dalam kajian kitab-kitab klasik menjadi pesantren gabungan (mixed), yang memadukan sistem tradisional dengan pendidikan modern dengan cara mendirikan sekolah formal (Ronald Lukens-Bull, 2010: 10-11). Perubahan orientasi ini mengisyaratkan bahwa pola kepemimpinan kiai di Pondok Pesantren al-Salafiyah lebih rasional dengan memasukan nilai-nilai modernitas di dalam sistem pendidikan pesantren.

Dalam hal manajemen pesantren, menurut Irwan Masduqi, KH. Syuja'i Masduki selaku pimpinan pesantren Salafiyah tidak begitu berperan. Segala hal tentang manajemen pesantren diserahkan kepada keempat puteranya dengan pembagian tugasnya masing-masing seperti takhassus Qur'an diserahkan kepada Gus Nur (Nur Hamid Masduqi), pengembangan keilmuan dan kurikulum diserahkan Gus Irwan (Irwan Masduqi), Gus Hasan (Hasan Abdullah) sebagai bendahara dan memegang pondok salafiyah sebelah timur. Kewenangan KH Syuja'i lebih pengambil kebijakan di pesantren. (Wawancara, 11 Oktober 2015).

Manajemen pendidikan di Pondok Pesantren Al-Miftah bagi santri putra dan putri dipimpin oleh dua kiai. Santri putra dipimpin Kiai Ubaidah sedangkan santri putri dipimpin Gus Mabarrun. Pesantren ini didirikan oleh Mbah Siruddin pada tahun 1932 yang sebelumnya dalam bentuk majelis pengajian kitab. Pesantren ini memiliki santri sekitar 55 santri (putra 43 dan putri 12). Selain mondok, para santri juga mengikuti sekolah formal dan ada juga yang sambil bekerja. Menurut ustadz Mausul Huda, manajemen pesantren di al-Miftah dipimpin oleh kiai dengan melibatkan pengurus pondok pesantren. Akan tetapi, dalam pengembangan kurikulum, sepenuhya menjadi wewenang kiai. (Wawancara, 17 Oktober 2015).

Kebijakan manajemen pesantren al-Miftah bagi santri putra dan putri berbeda. Menurut Mausul Huda, kebijakan untuk santri putri diatur oleh ndalem atau wewenang penuh kiai sedangkan kebijakan bagi santri putra dilakukan musyawarah kiai dengan 
pengurus secara demokratis. Sikap demokratis kiai melahirkan sikap moderasi di kalangan alumni pesantren. Hal ini dapat dibuktikan dengan beberapa alumni yang ikut bergabung dengan Muhammadiyah dan Jamaah Tabligh walaupun amaliyahnya masih NU (Wawancara, 17 Oktober 2015).

Kebijakan pesantren an-Nasyat berbeda dengan al-Miftah. Menurut Miqdam Makfi, kepemimpinan Pondok Pesantren AnNasyath tidak diserahkan kepada pengurus, tetapi masih dipegang oleh kiai. Sejarah Pondok Pesantren An-Nasyath berdiri pada tahun 1976 sebagai lembaga pendidikan non formal. Pengasuhnya bernama Bapak Kiai Haji Sami'an dan istrinya, Ibu Nyai Hajjah Handarotiyah. Misi pesantren an-Nasyath adalah mengajarkan ilmuilmu agama kepada para santrinya yang fokus pada akhlak dan fikih. Pesantren ini memiliki santri sekitar 120 (40 santri anak-anak dan 80 santri dewasa). Pesantren ini memiliki sekolah formal MI, MTs, dan MA bergabung dalam Yayasan Nur Iman. Alumni anNasyat ada yang aktif di lembaga pendidikan Muhammadiyah, namun amaliyahnya masih NU, seperti menjadi guru di sekolah Muhammadiyah. (Wawancara, 18 Oktober 2015).

Pondok Pesantren Aswaja Nusantara yang didirikan oleh Kiai Muhammad Mustafid pada tahun 2011 merupakan pesantren termuda di Mlangi. Idealisme kiai yang ingin diwujudkan adalah menciptakan santri yang religious, bervisi sangat luas, dan menginternasionalkan pemikiran santri. Aswaja Nusantara merupakan pesantren bagi pelajar dan mahasiswa yang sangat konsern dengan kajian-kajian keislaman yang menyebarluaskan ide-idenya melalui Jurnal Mlangi sebagai media pemikiran dan budaya pesantren (Mustafid, 2013).

Menurut Azzam Anwar Masduqi, jumlah santri Aswaja Nusantara sekitar 50 (30 putra dan 20 putri). Hampir semua santri berasal dari latar belakang NU. Santri dari pondok Aswaja Nusantara semua sedang menempuh sekolah baik di tingkat MI, MTs, MA maupun universitas. Dalam pengembangan kurikulum maupun pengembangan pondok, setiap gagasan selalu didiskusikan oleh dewan asatiz/dewan pengasuh dengan kiai. Jadi, setiap keputusan yang terkait pondok adalah keputusan bersama. Pola kepemimpinan kiai sangat demokratis (Wawancara, 24 Oktober 2015). 
Dari uraian di atas, pola kepemimpin di pesantren-pesantren Salafiyah Mlangi perspektif teori kepemimpinan Weber dapat dibagi menjadi tiga, yaitu tradisional, karismatik, dan rasional. Ketiga pola Weber tersebut tersebut terdapat dalam kepemimpinan kiai di Mlangi. Kepemimpinan tradisional kiai Mlangi sangat dipengaruhi oleh tradisi pendidikan pesantren yang sangat menghormati posisi kiai sebagai pimpinan pesantren, bahkan kiai sebagai pemilik pesantren. Tardisi pesantren juga mendorong para santri untuk bersifat tawadhu dengan sang kiai.

Kepemimpin karismatik di pesantren Salafiyah Mlangi didorong adanya sikap religiusitas kiai dan keteladanan akhlak Islam yang ditampilkan dalam kehidupan sehari-hari. Pola karismatik ini juga didukung tradisi tarekat di pesantren, misalnya di pesantren alSalafiyah, di samping menjadi pimpinan pesantren, kiai juga seorang Mursyid Thoriqah Naqsyabandiyah. Indikasi karisma kiai terdapat dalam ketaatan para pengurus dan santri di pesantren-pesantren Salafiyah Mlangi. Kiai merupakan pengambil kebijakan utama dalam pengembangan kurikulum dan pengembangan pesantren.

Kepemimpinan rasional nampak dalam pendelegasian manajemen pesantren. Banyak kiai yang mendelegasikan kepengurusan pesantren kepada anak-anaknya maupun para pengurus santri. Walaupun regenerasi kepemimpinan dilakukan secara geneologis, sikap demokratis kiai nampak, khususnya terdapat di kepemimpinan kiai pesantren Aswaja Nusantara. Selain itu, sikap rasional kiai diwujudkan dalam pengembangan orientasi pesantren Salafiyah menjadi pesantren gabungan (mixed), yaitu menggabungkan sistem pendidikan pesantren Salafiyah dengan pendidikan modern. Contohnya, banyak pesantren yang membuka sekolah-sekolah formal maupun mendorong para santri untuk sekolah formal di samping mondok di pesantren.

Untuk Pondok Pesantren al-Falahiyah dan Pesantren Putra al-Miftah yang menerapkan mekanisme musyawarah dalam urusan aturan dan kurikulum pesantren, maka hal itu merupakan langkah rasional. Walupun keputusan-keputusan yang diambil pengurus, pelaksanaannya harus persetujuan kiai. Dalam hal ini, kedua Pondok Pesantren tersebut memperahankan sifat kepemimpinan 
tradisional-rasional. Walaupun pola kepemimpinannya mengikuti pola-pola kharismatik-tradisional-rasional, akan tetapi sebenarnya lebih kepada gaya kepemimpinan paternalistik. Sebab, kebijakan kiai selaku pimpinan pesantren masih bersifat terlalu melindungi (over protective), yang jarang memberikan kesempatan kepada bawahan untuk mengambil keputusan.

\section{Strategi Kepemimpinan Kiai dalam Proses Ideologisasi Pemikiran Santri}

Tujuan pendidikan di Pondok Pesantren Falahiyah untuk menanamkan ideologi pemikiran Ahlussunah Waljamaah anNahdliyah. Menurut Gus Rifqi, penyebutan an-Nahdliyah penting karena jika hanya ahlussunah Waljamaah (Aswaja) saja, sudah banyak pihak dari organisasi Islam di Indonesia menyebut dirinya sebagai Aswaja, tetapi kontradiktif dengan paham Aswaja NU. Penanaman ideologi Aswaja NU telah dirintis oleh KH. Zamruddin dan Nyai Hajjah Rubai'ah selaku pendiri pesantren al-Falahiyah melalui kajian fikih, tauhid, akhlak, dan hafalan al-Qur'an. (Wawancara, , 3 Oktober 2015).

Pesantren Falahiyah juga melakukan monitoring terhadap alumninya. Monitoring ini dilakukan dalam rangka menjaga ideologi atau pemikiran alumni pesantren Falahiyah agar tetap dalam rel Aswaja an-Nahdliyah. Mekanisme monitoringanya dengan mendirikan perkumpulan alumni. Dengan pengawasan tersebut, hingga saat ini belum ada santri yang keluar dari amaliyah NU. Meski pernah ada yang masuk Muhammadiyah namun keluar lagi. Adapun alumni yang melanjutkan kuliah di UAD maupun UMY tetap amaliyahnya yang diajarkan di pesantren. (Wawancara, 3 Oktober 2015).

Strategi penguatan ideologi Pondok Pesantren as-Salafiyah ini berbeda dengan Pondok Pesantren al_Falahiyah. Menurut Irwan Masduqi, pesantren Salafiyah cenderung tidak melakukan indoktrinisasi yang ketat seperti Pesantren Falahiyah. Selama ini dasar keagamaan santri hampir semuanya NU, meski ada beberapa dari keuarga Muhammadiyah, tetapi warga Muhammadiyah tersebut dahulu juga menimba ilmu di pesantren NU. Karena pekerjaannya 
di lingkungan Muhammadiyah maka yang bersangkutan aktif di Muhammadiyah tetapi tetap tertarik kepada pesantren ala NU. Bahkan, pernah ada santri yang berasal dari ideologi Wahabi, karena mengira Salafiyah merupakan pesantren salaf perspektif ideologi Wahabi/Salafi. Pada akhirnya, yang bersangkutan tetap masuk dan amaliyah yang dilakukannya sama seperti yang dilakukan oleh santri-santri lainnya. (Wawancara, 11 Oktober 2015). Untuk penguatan pemikiran keagamaan dan pendidikan umum, Pesantren Salafiyah merintis sekolah formal pada tahun 2013 yaitu MTs dan pada tahun 2015 mulai mendirikan MA.

Pesantren Salafiyah memberikan pengajaran serta aturanaturan yang mendorong para santri untuk tekun belajar dan mengamalkan amalan-amalan sunah. Pesantren Salafiyah memberi kebebasan kepada alumni untuk memilih jalan hidupnya yang dianggap baik bagi dirinya. Menurut Gus Irwan, pesantren tidak membuat kontrol apapun terhadap pemahaman keagaman santri. Pertemuan alumni yang diselenggarakan pesantren minimal setiap tahun sebagai wadah silaturahmi bagi alumi dan bukan alat kontrol terhadap pemahaman keagamaan santri (Wawancara, 11 Oktober 2015).

Proses ideologisasi Aswaja bagi santri di Pondok Pesantren alMiftah mengalir sesuai tradisi yang sudah diajarkan oleh pendiri dan generasi penerusnya. Menurut Huda, penanaman ideologi Aswaja selama ini terbukti efektif walaupun tanpa ada inovasi-inovasi dalam kurikulum. Di bawah bimbingan Gus Mabarrun dan Nyai Isna, para santri ikut kegiatan yang dilakukan oleh NU, seperti LBM, Festivalfestival, dan lain-lain. (Wawancara, 17 Oktober 2015). Terdapat beberapa kegiatan keilmuan yang masih dipertahankan, antara lain: (1) Kegiatan seperti Babtsul Masa'il, (2) Tafaqqub fid din, fokus pada ilmu agama dengan adanya penyesuaian kitab-kitab tambahan. Selain itu juga terdapat usaha untuk menyiapkan santri agar memiliki entrepreneurship, misalnya bagi santri putra diajarkan kemampuan pertukangan sedangkan santri putri diajarkan keterampilan menjahit, dan (3) FORSIP: beberapa kegiatan seperti silaturahmi santri, mengkaji ilmu-ilmu yang sudah punah di pesantren seperti ilmu fikih, falaq, usul fikih, dan menerjemahkan kitab, serta ikut dalam agenda pekan pondok pesantren yang diadakan Kementerian Agama. 
Strategi Pondok Pesantren An-Nasyath dalam penanaman ideologi Aswaja melalui pembelajaran kitab-kitab usul fikih, fikih dan tauhid. Menurut Makfi, fikih yang dipelajari adalah fikih Syafi'iyah, tauhid mazhab Asy'aryiah Maturidiyah, dan akhlak atau sufisme imam al-Ghazali. Dalam menghadapi modernitas dan keragaman keberagamaan, Pesantren an-Nasyath mengadakan kajian lintas madzhab setiap jumat sore. Banyaknya tenaga pengajar yang memiliki pengalaman pendidikan tinggi lulusan Mesir, maka pengembangan lebih dinamis (Wawancara, 18 Oktober 2015).

Proses kajian dan pengajaran serta amaliah-amaliah Aswaja an-Nahdiyah serta teladan dari kiai merupakan sebuah proses penanaman ideologisasi santri. Para pengasuh yang keilmuannya lumayan tinggi ditambah wawasan kontemporer merupakan instrumen efektif dalam membentuk paradigma keilmuan santri. Pengangkatan pengasuh atau pengajar dilakukan oleh kiai langsung sebagai pimpinan pesantren dengan memperhatikan kapasitas kemampuan santrinya. Yang lebih ditegaskan dalam ideologisasi santri ini adalah pemberian contoh akhlak yang baik oleh kiai dan para pengasuhnya.

Kiai memiliki pengaruh yang sangat kuat dalam kepemimpinan di pesantren. Meskipun para pengasuh/ustaz mengajarkan ilmu yang lebih bebas, tetapi mayoritas santri masih ikut pada ilmu yang telah diajarkan oleh kiai. Meski ilmu yang diajarkan masih tradisional (kitab-kitab klasik), tapi dapat menghasilkan etika santri yang baik dan memiliki kemampuan membaca kitab yang bagus. Pemikiran yang tradisional dapat dipoles menjadi lebih modern dan rasional dengan semakin banyak ilmu yang dipelajari. Hal ini menjadi benteng dari gempuran-gempuran ideologi yang dapat merusak perilaku dan pikiran.

Pengawasan ideologi santri sampai saat ini masih terbatas pada komunitas alumni santri. Meski demikian, apabila ada indikasiindikasi yang mengarahkan santri di luar amaliyah NU, hal tersebut tidak begitu dipermasalahkan. Meski pada kenyataannya sudah diberikan wejangan oleh kiai, tetapi pada akhirnya diserahkan kepada alumni yang bersangkutan. Sebab, tanggung jawab alumni dalam pengamalan agama merupakan tanggung jawab personal. 
Adapun penanaman ideologi di Pondok Pesantren Aswaja Nusantara, menurut Azzam, melalui pemberian penjelasan perbandingan antara ideologi Aswaja dengan ideologi-ideologi yang ada di dunia. Pengetahauan teoretis ideologis ini sebagai pondasi keilmuan dan indentitas yang kuat untuk menghadapi pada faktafakta keragaman keberagamaan, selain bertujuan kepada penguatan identitas maupun ideologis santri. Santri diberikan bekal yang kuat dengan diwajibkannya mereka untuk banyak membaca yang kemudian akan direivew setiap minggu. Hasil dari membaca, santri harus mengembangkan dalam bentuk tulisan-tulisan. (Wawancara, 24 Oktober 2015).

Pemikiran kiai dan jaringan gerakannya yang luas menjadikan pesantren kaya akan keragaman ilmu pengetahuan, terutama bidang agama dan gerakan sosial. Hal itu didukung juga dalam hal pengembangan kemampuan bahasa Inggris. Para santri dibekali ilmu-ilmu gerakan sosial politik dan ilmu riset. Selain itu juga menjalin dengan lembaga-lembaga yang beragam, tidak hanya non Islam dan dalam negeri, tetapi lembaga non muslim dan lembaga jaringan gerakan luar negeri. Sehingga, pesantren ini sering menerima kunjungan-kunjunga baik dari lembaga NU maupun lembaga non-islam yang berasal dari dalam dan luar negeri. juga. Kunjuangan itu tidak hanya sekadar kunjungan saja, tetapi dalam bentuk diskusi sharing pengalaman kerberagamaan dan keragaman sosial keagamaan. (Wawancara, 24 Oktober 2015).

Kiai Aswaja Nusantara menjadi teladan dalam hal ideologisasi santri. Menurut Azzam, strategi kiai dalam melakukan ideologisasi santri dengan melibatkan para santri dalam kegiatan-kegiatan NU, seperti MAKESTA IPNU-IPPNU dan juga melibatkan para asatidz dalam kegiatan-kegiatan yang positif dan berdampak bagus, seperti Forum Komunikasi Penanggulangan Terorisme (FKPT). Selain itu, diadakan diskusi mingguan dengan para tokoh di bidangnya untuk memperkuat ideologi gerakan Aswaja santri (Wawancara, 24 Oktober 2015). 
Implikasi Kepemimpinan Kiai terhadap Pemikiran Keagamaan Santri

Kepemimpinan merupakan sebuah proses (aktivitas) mempengaruhi yang dilakukan oleh seorang pemimpin kepada pengikutnya untuk pencapaian tujuan, komitmen kelompok, dan perubahan budaya organisasi (Sadler, 1997:22). Dalam kepemimpinan menuntut ketaatan pengikut terhadap perintah pemimpin. Terdapat banyak pola (tipe) kepemimpinan (kiai) untuk mempengaruhi para pengikut (ustadz atau santri dalam tradisi pesantren).

Berdasarkan teori kepemimpinan Weber, tiga pola kepemimpinan (tradisional, karismatik, rasional) terdapat dalam kepemimpinan para kiai di pesantren Salafiyah Mlangi Yogyakarta. Tiga model kepemimpinan tersebut memberikan implikasi terhadap pemikiran keagamaan santri yang berbeda. Perbedaan ini dikarenakan sumber dominasi yang berbeda. Sebagaimana dikutip Kurdi (2007:134), konsep kepemimpinan Weber berdasarkan pada konsep dominasi. Penjelasan lebih detail bisa dilihat di tabel berikut ini.

\section{Tabel.1 \\ Konsep Dominasi Weber}

\begin{tabular}{clll}
\hline $\begin{array}{c}\text { Bentuk } \\
\text { Dominasi }\end{array}$ & \multicolumn{1}{c}{ Sumber } & Kepemimpinan & Perubahan \\
\hline Tradisional & Non-rasional & Kebiasaan & Statis \\
Karismatik & $\begin{array}{l}\text { Pengaruh } \\
\text { (emosional }\end{array}$ & $\begin{array}{l}\text { Pribadi/ } \\
\text { perorangan }\end{array}$ & Dinamis \\
Rasional & Rasional & $\begin{array}{l}\text { Kekuasaan } \\
\text { impersonal }\end{array}$ & Dinamis \\
\hline
\end{tabular}

Dari tabel di atas dapat disimpulkan bahwa dominasi kepemimpinan tradisional bersumberkan pada non-rasional dan kebiasaan (tradisi) yang melekat sehingga tidak banyak perubahan (statis) dalam sebuah organisasi yang dipimpinnya. Hal ini terjadi dalam masyarakat-masyarakat tradisional yang memegang teguh tradisi. Kepemimpinan tradisional juga terdapat di beberapa pesantren tradisional yang masih memegang teguh tradisi pendidikan Islam konvensional, misalnya hanya mengkaji kitab-kitab klasik. 
Kepemimpinan tradisional di pesantren-pesantren Salafiyah di Mlangi terdapat dalam sikap para kiai dalam mempertahankan kajian-kajian kitab-kitab klasik dan tradisi pendidikan Islam yang menekankan pada kemandirian dan ketaatan santri kepada kiai. Ketaatan ini bukan karena dominasi seorang kiai, tapi dikarenakan oleh tradisi di pesantren yang mendorong para santri untuk taat kepada kiainya. A. Musthofa Bisri (dalam Baddrut Tamam, 2015: xxii-xiv) kurang sepakat jika ketaatan santri kepada kiai merupakan sesuatu yang sengaja ditekankan di pesantren dan berlebih-lebihan kalau itu dianggap sebagai 'kepatuhan doktrinal' dan kepatuhan mitologis. Akan tetapi, ketaatan ini memang muncul karena kedekatan kiai kepada santrinya secara batiniyyah. Banyak para kiai yang memikirkan, mendidik, mengajar, dan mendoakan para santri tanpa pamrih. Sikap seperti inilah yang mendorong santri untuk taat kepada kiainya.

Implikasi kepemimpinan tradisional di pesantren adalah terjadinya pergantian kepemimpinan kiai yang dilakukan secara geneologis dari keturunannya maupun saudaranya. Hal ini juga terjadi di pesantren-pesantren Salafiyah Mlangi. Sedangkan implikasi kepemimpinan tradisional terhadap pemikiran santri adalah adanya ketaatan (fanatisme) santri untuk mengikuti pemikiran keagamaan kiai, walaupun di beberapa pesantren ada kebebasan berpikir. Sikap fanatisme inilah yang menjadikan para alumni pesantren Salafiyah memiliki ideologi keagamaan yang sama dengan kiainya. Hal ini berbeda dengan pendidikan Islam di pesantren modern, semisal Gontor.

Kepemimpinan karismatik bersumberkan pada pengaruh (emosional) para pengikutnya dan biasanya karisma tersebut muncul dari nilai kepribadian seorang pemimpin. Dalam tradisi pesantren, kepemimpinan karismatik muncul dari tingginya ilmu yang dimiliki kiai, taatnya terhadap ajaran Islam, akhlak yang mulia dan memiliki maqam tertinggi dalam tarekat, misalnya makrifat (Abdul Gaffar Karim (2009: 103), Horikoshi (1987: 226-227). Implikasi dari kepemimpinan karismatik adalah terjadinya perubahan dinamis dalam organisasinya. Dalam pesantren, kepemimpinan karismatik mendorong perubahan dinamis dan ketaatan para ustadz, santri, dan masyarakat sekitar pesantren, sehingga kiai menjadi aktor perubahan sosial. 
Kepemimpinan karismatik di pesantren-pesatren Salafiyah Mlangi terdapat dalam sikap ketaatan santri kepada kiainya. Perbedaan dengan kepemimpinan tradisional, dalam ketaatan kepemimpinan karismatik didorong oleh hubungan emosional para santri dan keyakinan bahwa kiai merupakan teladan terbaik dalam menjalankan ajaran Islam (perilaku religius), memiliki akhlak mulia, ilmu yang tinggi, dan posisi sebagai seorang mursyid dalam tarekat. Gambaran kiai seperti inilah yang memunculkan karisma dalam diri kiai sehingga para santri sangat menghormati dan taat kepadanya. Ketaatan santri kepada kiai bukan didorong karena tradisi sebagaimana dalam kepemimpinan tradisional yang lebih menekankan pada ketaatan tradisi.

Implikasi kepemimpinan karismatik terhadap pemikiran keagamaan santri adalah para santri bisa bersikap lebih fanatik karena didorong oleh hubungan emosional (batiniyyab) kepada kiai karena santri mengganggap bahwa kiai adalah potret teladan terbaik dalam menjalankan ajaran Islam secara sempurna. Santri akan semakin yakin dan taat untuk mengikuti jejak spiritualitas kiai jika dalam diri kiai muncul "karomah" atau kelebihan-kelebihan yang tidak dimiliki oleh semua orang (kiai), misalnya kiai dapat menyembuhkan orang sakit dengan doa atau kiai dapat membaca 'tanda' pada diri seseorang (baca cerpen A. Mushtofa Bisri "Gus Ja'far" dalam Akhmad Sahal dan Munawir Aziz (ed.), 2015: 181), dan lain sebagainya.

Kepemimpinan rasional merupakan kepemimpinan yang didasarkan pada rasionalitas dan kekuasaan impersonal. Kepemimpinan rasional biasanya terdapat dalam organisasiorganisasi modern yang mengandalkan konsensus bersama bukan faktor geneologi dalam pemilihan (pergantian) pemimpin. Dalam kepimpinanan rasional mudah terjadi perubahan secara dinamis karena pengambilan keputusan seringkali dilakukan secara musyawarah dan demokratis.

Bentuk kepemimpinan rasional yang terdapat di pesantren Mlangi adalah kebijakan didirikannya sekolah-sekolah formal di bawah payung pendidikan pesantren. Sekolah formal ini untuk memberikan pengetahuan umum bagi para santri agar lebih 
siap dalam menghadapi perubahan zaman dan arus globalisasi. Kebijakan tersebut berdampak pada perubahan orientasi dan tipologi pesantren Salafiyah menjadi pesantren gabungan (mixed) yang menggabungkan sistem pendidikan tradisional dan pendidikan modern. Pendidikan modern dalam bentuk sekolah maupun madrasah yang mengajarkan ilmu-ilmu sains dan humaniora.

Implikasi kepemimpinanan rasional kiai terhadap pemahaman keagamaan santri, bahwa santri tidak lagi berfikir dikotomik dalam memahami Islam dan sains. Pendirian sekolah formal bertujuan untuk mengenalkan para santri bahwa Islam juga mengapresiasi ilmu-ilmu umum (sains dan humaniora), sehingga santri lebih siap menghadapi perubahan zaman. Di samping itu, para santri juga diajarkan kitab-kitab yang ditulis oleh tokoh muslim modern, seperti yang dilakukan Gus Irwan Masduqi di pesantren Salafiyah Mlangi, misalnya kitab karya Ibn Rusyd, Sayyid Quthb, Wahbah Zuhaili, dan lain-lain. (Wawancara, 11 Oktober 2015).

Dari uraian di atas dapat disimpulkan bahwa ketiga tipe kepemimpinan kiai di pesantren-pesantren Salafiyah Mlangi memiliki implikasi terhadap pemikiran keagamaan santri yang berbeda. Lebih jelasnya dapat diringkas dalam tabel di bawah ini:

\section{Tabel.2}

Konsep Kepemimpinan Kiai di Pesantren Salafiyah Mlangi dan Implikasinya terhadap Pemikiran Keagamaan Santri

\begin{tabular}{|c|c|c|}
\hline Tipe & Bentuk & Implikasi \\
\hline Tradisional & $\begin{array}{l}\text { Ketaatan santri kepada kiai } \\
\text { karena tradisi pendidikan } \\
\text { pesantren dan kajian } \\
\text { pesantren yang fokus pada } \\
\text { kitab-kitab klasik (kuning) }\end{array}$ & $\begin{array}{l}\text { Sikap fanatik santri untuk } \\
\text { mengikut pemikiran } \\
\text { keagamaan }\end{array}$ \\
\hline
\end{tabular}




\begin{tabular}{|c|c|c|}
\hline Karismatik & $\begin{array}{l}\text { Ketaatan santri kepada } \\
\text { kiai karena karisma } \\
\text { yang muncul dari nilai } \\
\text { kepribadian kiai (akhlak, } \\
\text { ilmu yang tinggi, karomah, } \\
\text { dan lain-lain) }\end{array}$ & $\begin{array}{l}\text { Sikap fanatik santri untuk } \\
\text { mengikuti pemikiran } \\
\text { keagamaan kiai }\end{array}$ \\
\hline Rasional & $\begin{array}{l}\text { Perubahan orientasi } \\
\text { pendidikan pesantren } \\
\text { Salafiyah menjadi pesantren } \\
\text { Gabungan (mixed) antara } \\
\text { sistem tradisional dan } \\
\text { pendidikan modern, } \\
\text { contohnya mendirikan } \\
\text { sekolah formal. Selain itu, } \\
\text { dikaji kitab-kitab karya } \\
\text { tokoh muslim kontemporer, } \\
\text { misalnya Ibn Rusyd, Sayyid } \\
\text { Quthb, Wahbah Zuhaili. }\end{array}$ & $\begin{array}{l}\text { Santri tidak memiliki } \\
\text { pandangan dikotomik } \\
\text { antara ilmu agama dan } \\
\text { sains. Di samping itu, } \\
\text { santri memiliki wawasan } \\
\text { pengetahuan Islam } \\
\text { yang lebih luas dengan } \\
\text { adanya kajian kitab-kitab } \\
\text { kontemporer. }\end{array}$ \\
\hline
\end{tabular}

\section{Kesimpulan}

Berdasarkan hasil pembahasan di atas, penelitian ini dapat simpulkan, pertama, tipologi kepemimpinan kiai di Pesantrenpesantren Salafiyah Mlangi berdasarkan teori dominasi Weber yang terdapat di pesantren Salafiyah Mlangi, yaitu tradisional, kharismatik, dan rasional. Kepemimpinan tradisional sangat dipengaruhi oleh tradisi pendidikan pesantren yang sangat menghormati posisi kiai sebagai pimpinan pesantren, bahkan kiai sebagai pemilik pesantren. Kepemimpin karismatik di pesantren Salafiyah Mlangi didorong adanya sikap religiusitas kiai dan keteladanan akhlak Islam yang ditampilkan dalam kehidupan sehari-hari. Pola karismatik ini juga posisi kiai menjadi Mursyid Thoriqah Naqsyabandiyah dan kiai memiliki karomah. Kepemimpinan rasional nampak dalam pendelegasian manajemen pesantren dan pengembangan orientasi pesantren Salafiyah menjadi pesantren gabungan (mixed) dengan menggabungkan sistem pendidikan pesantren Salafiyah dengan pendidikan modern. 
Kedua, ideologi yang dianut adalah Ahlussunah Waljamaah (Aswaja) an-Nahdliyah dan strategi ideologisasi santri yang dilakukan oleh kiai melalui kajian kitab-kitab klasik bermadzab Aswaja anNahdliyah, penguatan peran alumni, melestarikan tradisi pesantren Salafiyah, Babtsul Masa'il dan Tafaqqub fiddin, kaderisasi dengan keikutsertaan pada organisasi NU, dan kajian lintas madzhab (ideologi) dan Ketiga, implikasi tipe kepemimpinan kiai terhadap pemikiran santri adalah sikap fanatik santri dalam mengikuti pemikiran keagamaan kiai (dipengaruhi kepemimpinan tradisional dan karismatik), santri tidak memiliki pandangan dikotomik antara ilmu agama dan sains dan memiliki wawasan pengetahuan Islam yang lebih luas dengan kajian kitab-kitab Islam kontemporer (dipengaruhi kepemimpinan rasional).

\section{Daftar Pustaka}

Arifin, Zainal. 2012. "Menangkal Islam Radikal, Upaya Santri Mlangi Yogyakarta dalam Mencegah Infiltrasi Paham Islam Radikal", An-Nur Jurnal Studi Islam STIQ an-Nur Yogyakarta, Vol. IV, No.1: 93.

Arifin, Zainal. 2012. "Perkembangan Pesantren di Indonesia," Jurnal Pendidikan Agama Islam., Fakultas Tarbiyah dan Keguruan UIN Sunan Kalijaga Yogyakarta, Vol.IX, No.1: 47.

Bull, Ronald Lukens. 2010. "Madrasa by Other Name Pondok, Pesantren, and Islamic School in Indonesia and Larger Southeast Asian Region", Journal of Indonesian Islam, Program Pascasarjana-Lembaga Studi Agama dan Sosial IAIN Sunan Ampel Surabaya, Vol. 4, No. 1: 10-11.

Dhofier, Zamakhsari. 2011. Tradisi Pesantren Studi Tentang Pandangan Hidup Kiai dan Visinya Mengenai Masa Depan Indonesia,cet. Ke-9, Jakarta: LP3ES.

Horikoshi, Hiroko. 1987. Kiai dan Perubahan Sosial,(terj.) oleh Umar Basalim dan Andi Muarly Sunrawa, Jakarta: P3M.

Karim, Abdul Gaffar. 2009. "The Pesantren-Based Ruling Elite in Sumenep in the Post-New Order in Indonesia", Journal of 
Indonesian Islam, IAIN Sunan Ampel Surabaya, Vol.03, No.01: 103.

Kurdi, Sulaiman. 2007. "Peranan Elit Ulama di Negeri Para Mullah (Studi Pemikiran Khomeini tentang Wilayatul Faqib), Hermeneia Jurnal Kajian Islam Interdisipliner, Pascasarjana UIN Sunan Kalijaga Yogyakarta,Vol.6 No. 1: 134.

Miles, B. M., \& Huberman, A. M. 1984. Qualitative Data Analysis, London New Delhi: Sage Publications.

Pesantren "Pelajar Mahasiswa" Aswaja Nusantara. 2014. Jurnal Mlangi, Vol. 1, No. 3.

Rohmaniyah, Inayah dan Woodward, Mark. 2012. "Wahhabism, Identity and Secular Ritual: Graduation at an Indonesian High School", al-Jami'ah Journal of Islamic Studies UIN Sunan Kalijaga Yogyakarta, Vol.50, No.1: 123.

Romas, Chumaidi Syarif. 2003. Kekerasan di Kerajaan Surgawi, Yogyakarta: Kreasi Wacana.

Rozaki, Abdur. 2004. Menabur Kharisma Menuai Kuasa, Kiprah Kiai dan Blater sebagai Rezim Kembar di Madura, Yogyakarta: Pustaka Marwa.

Sadler, Philip. 1997. Leadership, London: Kogan Page Limited, 1997.

Sahal, Akhmad dan Aziz, Munawir (ed.). 2015. Islam Nusantara dari Ushul Fiqh hingga Paham Kebangsaan. Bandung: Mizan.

Steenbrink, Karel A. 1986. Pesantren Madrasah Sekolah Pendidikan Islam dalam Kurun Modern, Jakarta: LP3ES.

Subhan, Arief. 2012. Lembaga Pendidikan Islam di Indonesia Abad ke-20, Pergumulan antara Modernisasi dan Identitas, Jakarta: Kencana.

Sugiyono. 2010. Metode Penelitian Pendidikan Pendekatan Kuantitatif, Kualitatif, dan R\&D. Bandung: Alfabeta.

Sukamto. 1999. Kepemimpinan Kiai Dalam Pesantren, Jakarta: Pustaka LP3ES. 
Tamam, Baddrut. 2015. Pesantren Nalar dan Tradisi, Yogyakarta: Pustaka Pelajar.

Tim Penyusun Kamus Pusat Bahasa. 2002. Kamus Besar Bahasa Indonesia, Jakarta: Balai Pustaka.

Turner, Bryan S. 1974. Weber and Islam, a Critical Study, London: Routledge \& Kegan Paul.

Wahid, Abdurrahman, 1995. Pesantren Sebagai Subkultur dalam M. Dawam Rahardjo (ed.) Pesantren dan Pembaharuan,cet. ke5, Jakarta: LP3ES. 